\title{
Population Dynamics of Wild Reindeer (Rangifer tarandus L.) on the Taimyr Peninsula: A Simulation Model
}

\author{
N. V. Malygina ${ }^{a}$, K. V. Maklakov ${ }^{b}$, and F. V. Kryazhimskiy ${ }^{b}$ \\ ${ }^{a}$ Ural Federal University, ul. Mira 19, Yekaterinburg, 620002 Russia \\ e-mail: adelaviza@gmail.com \\ ${ }^{b}$ Institute of Plant and Animal Ecology, Ural Branch, Russian Academy of Sciences, \\ ul. Vos'mogo Marta 202, Yekaterinburg, 620144 Russia \\ e-mail:fvk@ipae.uran.ru \\ Received January 10, 2013
}

\begin{abstract}
A simulation model, based on original and published data, has been developed to determine the period and amplitude of natural population cycles of wild reindeer on the Taimyr Peninsula and reveal the role of hunting in these cycles. The results of simulations show that hunting in the late 20th century has smoothed out the cycles. Considering natural factors of population regulation, uncontrolled elimination of part of the population by hunting should maintain the average long-term abundance at a level lower than potentially possible under natural dynamics, leading to negative ecological and economic consequences.
\end{abstract}

Keywords: simulation modeling, population demographics, wild reindeer, population cycles, role of exploitation

DOI: $10.1134 / \mathrm{S} 1067413613050093$

The study of mechanisms controlling animal population dynamics is one of the central issues in modern population ecology (Pianka, 1974; Odum, 1983). Problems of population dynamics of domestic and wild reindeer in the circumpolar region attract growing attention. For instance, domestic reindeer on the Yamal Peninsula are one of the main factors influencing the state of natural systems and vegetation resources (Kryazhimskiy et al., 2010). The situation with wild reindeer is different because their abundance is not stimulated artificially, although some attempts at regulating it have been made (Malygina, 2005).

The growth of the wild reindeer population recorded on the Taimyr Peninsula over the past few decades raises a number of questions, important both practically and scientifically. The foremost of them are as to what are the factors that limit population growth and whether and to what extent this growth can continue, as well as whether tundra ecosystems will suffer from a rapid increase in wild reindeer abundance. This means that sound answers are needed to the question whether the wild reindeer population should be controlled by hunting (this approach has, among others, an economic component), and, if yes, how such control should be implemented. These questions are associated with fundamental notions on natural regulatory mechanisms of population dynamics.

The stability of the dynamic regimes of consumer species populations, i.e., their tendency toward a sta- ble regime-which is often cyclic, implying that the pressure exerted on the lower trophic levels is also cyclic but stable on a long-term scale-is largely determined by the relative size of different sex-age groups. This is one of the fundamentals of modern population demographics (Caughley, 1977; Shvarts, 1980). In this study, we tried to test the hypothesis that the population dynamics of wild reindeer on the Taimyr Peninsula should have a dynamic stable regime that is cyclic due to natural regulatory mechanisms. We used simulation (computer) modeling as the main instrument of system analysis. Our description of the population dynamics of wild reindeer was based on the classic Verhulst-Pearl model (logistic growth), with time lag effect taken into account (logistic differential model with a lag), and on Leslie matrices based on demographic tables. The parameters of the model were determined from our original data, published data of other authors, and expert estimations, and the realization of the model was performed in the licensed simulation modeling environment AnyLogic University 6.0 .

\section{MATERIAL AND METHODS}

This study was performed on the population of wild reindeer (Rangifer tarandus L.) living within the limits of the Taimyr Peninsula (this is probably part of a "metapopulation" that has a wider distribution, but the problem requires special studies). The results of 
Demographic data obtained during local field censuses (the Kheta-Boyarka River) and from Pavlov et al. (1985)

\begin{tabular}{|c|c|c|c|c|c|c|c|c|c|}
\hline \multirow{2}{*}{ Age, years } & \multicolumn{2}{|c|}{ Year } & \multirow{2}{*}{$\begin{array}{l}\text { Average sur- } \\
\text { vival rate, } l_{x}\end{array}$} & \multirow{2}{*}{$\begin{array}{c}\text { Percentage } \\
\text { of barren } \\
\text { females }\end{array}$} & \multicolumn{2}{|c|}{ Sex ratio } & \multirow{2}{*}{$\begin{array}{l}\text { Birth rate, } \\
\qquad m_{x}\end{array}$} & \multirow{2}{*}{$\begin{array}{l}\text { Newborns } \\
\text { in } 1991\end{array}$} & \multirow{2}{*}{$l_{x} m_{x} e^{-r x}$} \\
\hline & 1990 & 1991 & & & males & females & & & \\
\hline 0 & 146 & 214 & 1 & 100 & 1 & 2.6 & 0.00 & 0 & 0 \\
\hline 1 & 80 & 101 & 0.51 & 100 & 1 & 2.7 & 0.00 & 0 & 0 \\
\hline 2 & 109 & 123 & 0.66 & 100 & 1 & 2 & 0.00 & 0 & 0 \\
\hline 3 & 97 & 135 & 0.65 & 53.7 & 1 & 1.4 & 0.31 & 38.00 & 0.178 \\
\hline 4 & 95 & 116 & 0.60 & 17.5 & 1 & 1.5 & 0.48 & 64.97 & 0.254 \\
\hline 5 & 62 & 93 & 0.43 & 17.5 & 1 & 1.3 & 0.50 & 57.42 & 0.225 \\
\hline 6 & 37 & 63 & 0.27 & 17.5 & 1 & 1.3 & 0.47 & 43.37 & 0.143 \\
\hline 7 & 22 & 44 & 0.18 & 17.5 & 1 & 1.6 & 0.47 & 29.38 & 0.085 \\
\hline 8 & 15 & 26 & 0.11 & 17.5 & 1 & 1.2 & 0.51 & 22.34 & 0.056 \\
\hline 9 & 10 & 12 & 0.06 & 32.4 & 1 & 3 & 0.37 & 9.59 & 0.024 \\
\hline 10 & 7 & 7 & 0.04 & 32.4 & 1.3 & 1 & 0.51 & 6.08 & 0.017 \\
\hline 11 & 3 & 3 & 0.02 & 32.4 & 1 & 2 & 0.29 & 2.06 & 0.006 \\
\hline 12 & 0 & 2 & 0.00 & 32.4 & 0 & 2 & 0.45 & 1.35 & 0.004 \\
\hline 13 & 1 & 2 & 0.01 & 32.4 & 0 & 2 & 0.68 & 1.35 & 0.001 \\
\hline 14 & 1 & 1 & 0.01 & 32.4 & 1 & 0 & 0.68 & 1.35 & 0.002 \\
\hline 15 & 1 & 1 & 0.01 & 32.4 & 0 & 1 & 0.68 & 0.68 & 0.002 \\
\hline 16 & 0 & 1 & 0.00 & 32.4 & 0 & 1 & 0.68 & 0.68 & 0.001 \\
\hline$\Sigma$ & 686 & 944 & & & & & & 278.57 & 1 \\
\hline
\end{tabular}

on-ground and aerial observations made it possible to assess the seasonal dynamics and structure of moving reindeer groups. The age of the animals killed by hunters was determined from the layered structures of the incisors (Klevezal and Kleinenberg, 1967; Klevezal, 2007). The craniological material was collected from hunting stations at river crossings (on the KhetaBoyarka River) and enclosures (at the Kheta River and Amakai Brook) on the Eastern Taimyr Peninsula. For subsequent differentiation between males and females, the heads of killed males were marked with red paint. The hunting of wild reindeer at river crossings begins at the end of the first ten days of August and peaks usually around August 25 to September 7. Culling on land (in enclosures) is performed during the first ten days of October and usually peaks around October 10 to 20. Laboratory analysis of the materials was performed in the Extreme North Agricultural Research Institute (Norilsk).

\section{DEMOGRAPHIC MODEL EXPLAINED}

As noted above, the general dynamics of wild reindeer population density was simulated using a logistic growth model with a lag (May, 1976), for which only three parameters should be selected: growth rate $(r)$, carrying capacity of the environment $(K)$, and time lag of the response of the population to changes in its density (population inertia, $\tau$ ).

The Verhulst-Pearl logistic equation implies the existence of a limiting value of population size, known (in the canonic terminology) as the carrying capacity, $K$. The logistic equation with a lag can be written in the differential form as

$$
\frac{d N}{d t}=N_{t} r\left(1-\frac{N_{t-\tau}}{K}\right)
$$

where $t$ is the simulated time, $\tau$ is the time lag, and $N_{t}$ is the population size at moment $t$.

In nature, especially at high latitudes, animals respond to regular seasonal changes in environmental conditions (for instance, reindeer breed only once a year, like many other mammals with long life spans). Therefore, it is more adequate to express population growth in a discrete form, i.e., with annual increment corresponding to the exponent of the Malthusian parameter $\lambda=e^{r}$. Since the seasonal factor plays no substantial role in the demographic behavior of the population and the data of field studies are strictly distributed over years, simulation modeling was per- 
formed in a discrete form, with one step of the model standing for 1 year.

\section{ESTIMATION OF THE PARAMETERS OF THE TAIMYR WILD RAINDEER POPULATION}

The values of parameters used in the model were obtained from empirical data, without trying to adjust them to the observed population dynamics.

The instantaneous specific growth rate of the population $(r)$ was determined from a demographic table based on characteristics of different age groups (Caughley, 1977). The calculations were made on the basis of data on the age structure of the population in 1990 and 1991 and on birth rate, including data on barrenness and sex ratios; hence, columns of these parameters were also included in the table. The data were obtained in the course of field censuses performed at hunting stations and needed no smoothing and statistical processing for substituting into the standard Euler-Lotka equation. The parameter of growth rate $R$ in the extreme right column was selected considering the influence of the density-dependent factor (carrying capacity saturation), presumably foodrelated, i.e., $R=r\left(1-\frac{N}{K}\right)$.

Judging by the general increase in reindeer abundance between 1990 and 1991 and high survival rates in the most reproductive age groups, not only population growth but also in-migration of reindeer from other parts of their range takes place (Fig. 1). According to various data (Malygina, 1997, 1998, 2002, 2005, 2010), an intense migration flow directed mainly from the northwest to the southeast of the Taimyr Peninsula was observed in these years (corresponding to the population growth phase).

Taking into account not only seasonal migrations but also long-term migrations over the entire Taimyr Peninsula (Michurin, 1965; Geller, 1975; Syroechkovskii, 1986; Malygina, 1997, 1998, 2002, 2005, 2010), the reindeer population of the whole peninsula could be regarded in first approximation as a closed system. The accepted value of carrying capacity, $K=$ 800 ind., is based on expert estimations (Michurin, 1965; Geller, 1975; Kolpashchikov, Kuksov, and Pavlov, 1983).

The Malthusian parameter (instantaneous growth rate) for the Taimyr reindeer population was calculated in accordance with the main demographic formula, the Euler-Lotka equation (Caughley, 1977). Fitting of the parameter $R$ from the equation $\sum_{x=0} l_{x} m_{x} e^{-R x}=1$ by the recursive method from data of the demographic table yielded $R=0.068$. Since the instantaneous growth rate of the population $R$ determined for 1990-1991 depends on the carrying capac-

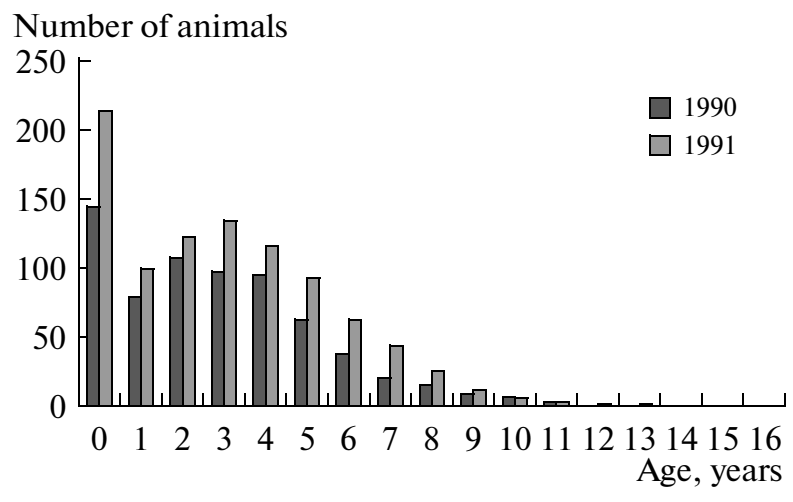

Fig. 1. Age structure of wild reindeer population in 1990 and 1991 .

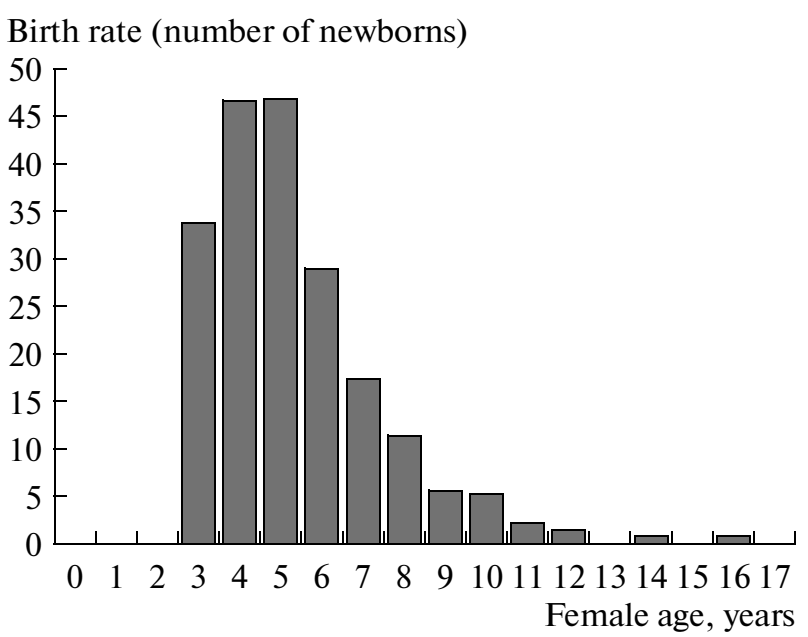

Fig. 2. Distribution of absolute birth rates in age groups of reproductive females in 1990 , based on the demographic table.

ity saturation, $R=r\left(1-\frac{N}{K}\right)$, and the size of the Taimyr population in those years is estimated at around 600000 ind. (Fig. 3), i.e., three-fourths of the carrying capacity $(N=600000, K=800000)$, the Malthusian parameter $r$ for the logistic model, independent of carrying capacity, is estimated as $r=0.27$. Transformation of the value of this parameter from the differential to discrete form yields the value of the annual growth coefficient $\lambda=e^{r}=1.32$.

The lag time $\tau$ in ecological modeling can be interpreted differently, e.g., as the population average time to reproductive maturity (May, 1975) or as the average individual life span (Kapitsa, 1999). We followed the former interpretation, and estimated the time lag $\tau$ between population growth and population size at 5.33 years (close to the average age of reproductive females) (Fig. 2). 


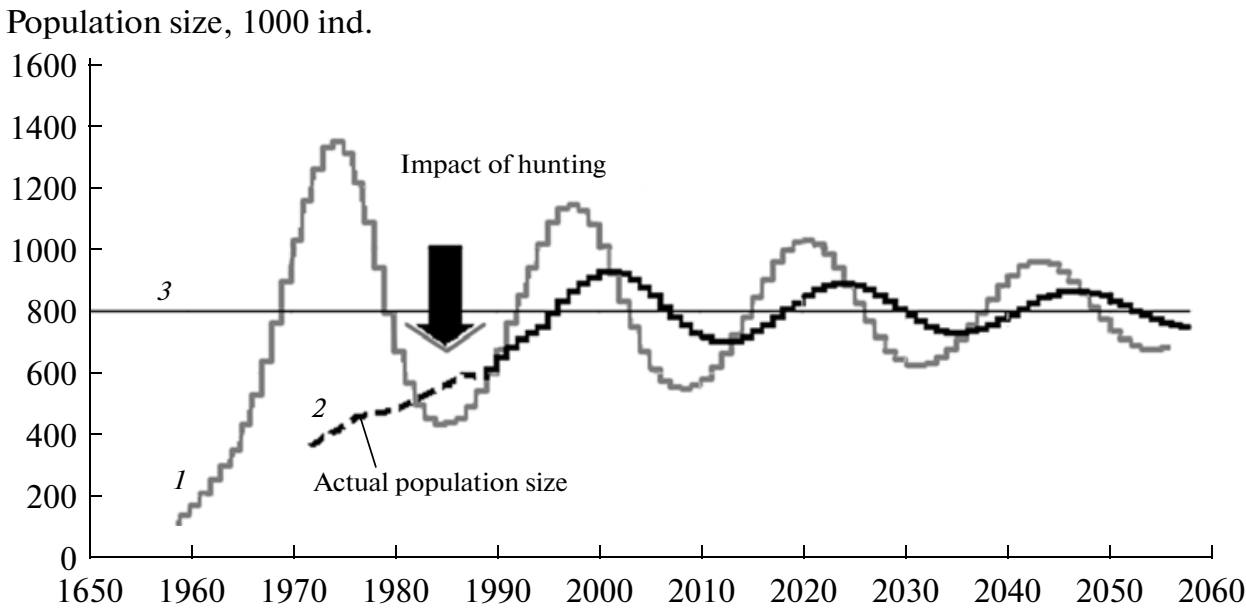

Fig. 3. Simulations of wild reindeer population dynamics on the Taimyr Peninsula under different initial conditions. Initial population size: (1) as of 1959, (2) as of 1989; (3) carrying capacity of the environment.

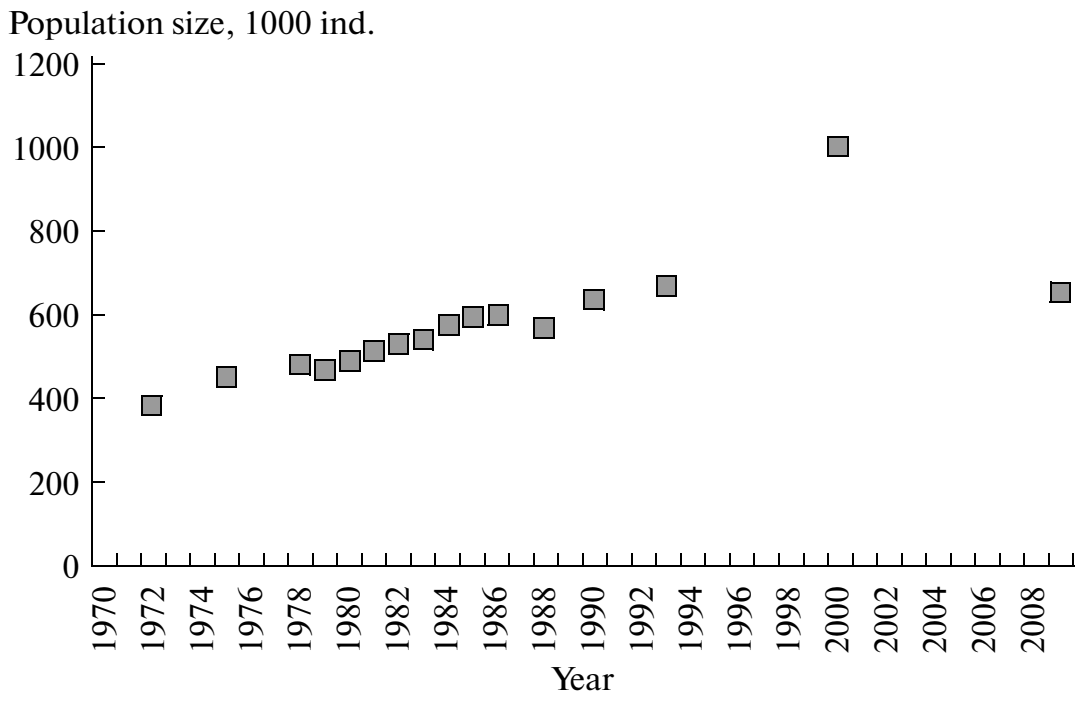

Fig. 4. Population dynamics of wild reindeer on the Taimyr Peninsula according to the CARMA (CircumArctic Rangifer Monitoring and Assessment) Network.

\section{SIMULATIONS AND DISCUSSION}

Asymptotic properties (convergence to a stationary state) of solutions to the initial nonlinear equation were proved using the Kakutani theorem and Markus theorem (Svirezhev and Logofet, 1978). In particular, at $1 / e<r \tau<37 / 24$, population size always oscillates, but in the absence of external disturbances these oscillations are decaying; at $r \tau<1 / e$, the behavior of a system with a lag is not different from the behavior of a system without a lag; at $r \tau>\pi / 2$, no stable equilibrium exists in the population (i.e., the regime is chaotic). At the values we obtained empirically, $r \tau=0.27 \times 5.33 \approx$ 1.45 , decaying oscillations should be observed.

Simulation of the model with the selected values of the parameters yields the expected ("natural") wild reindeer population dynamics in the form of decaying cycles with a 23 -year period (Fig. 3), approximately equal to $4 \tau$ as follows from the constructs of May (1976). The simulation with an initial population size of 570000 ind., as of 1989, yields the results almost identical to the wild reindeer population dynamics subsequently recorded on the Taimyr Peninsula. At the same time, the simulation with an initial population size of 110000 ind., as of 1959 (Andreev, 1961), yields a cycle with a considerable amplitude (up to $1.4 \times 10^{6}$ ind.), which has never been observed on the Taimyr Peninsula in reality according to data from the Extreme North Agricultural Research Institute and CircumArctic Rangifer Monitoring and Assessment Network (CARMA) (Fig. 4). The time gaps in the data are explained by irregularity of censuses in the 1990s 
and 2000s because of a difficult political and economic situation.

The simulations performed with the given parameters reflect the observed and potentially possible cyclic dynamics of the wild reindeer population of the Taimyr Peninsula, supporting the chosen model and its assumptions. A methodologically similar study (Messier et al., 1988) on the long-term dynamics of a comparable caribou population in the Labrador Peninsula yielded a similar result as to the population growth rate, $r=0.07$, when a logistic model with a time lag was used. Unfortunately, the authors of that study fitted their parameters on the basis of a simple exponential model of population growth $(r=0.11)$, contradicting their own assumption about foodrelated regulation of population size. In an attempt to apply the logistic model, those authors used a lag time equal to the period of vegetation regeneration $(\tau=$ 20 years), instead of the reproductive lag of the caribou themselves, and did not consider the carrying capacity of the environment. As a result, the model could not explain the 100-fold growth of the caribou population over a period of 30 years (from 4700 to 472200 between 1954 and 1984) and produced unrealistic cyclic dynamics of population size in the simulation of the model with a lag.

In our case, however, comparison of the expected and real data indicated the absence of cyclic reindeer population growth over the last decades of the 20th century, instead of its surge reasonably expected according to the model. A probable explanation is that the control simulation did not take into account the impact of intensive and unregulated hunting, which probably ceased in the late 1980s to early 1990s.

Simulations accounting for various types of hunting pressure (culling of the reindeer) (Fig. 5) showed that the lack of cyclic dynamics observed before 1988 is possible only in the case of linear and accelerated (exponential in the model) dependence of mortality from hunting on the reindeer population size (functional responses of the first and third types, respectively) (Fig. 6).

The functional response of the third type is unlikely, because humans organizing large-scale reindeer hunting can hardly be regarded as polyphagous predators switching their prey to reindeer with an increase in reindeer population size. The functional response of the first type is more probable and better conforms to the observed reindeer population dynamics. Such a linear dependence is typical of passive consumers, i.e., those not engaged in active (energyintensive) search for and utilization of their food. In particular, this concerns herbivorous species such as reindeer, which feed on lichens (White et al., 1981); lemmings, which feed in cotton grass-sedge communities (Batzli et al., 1981); or Daphnia, which filter suspended yeast cells out of the water (according to Rigler, 1961).
Number of reindeer taken, 1000 ind.

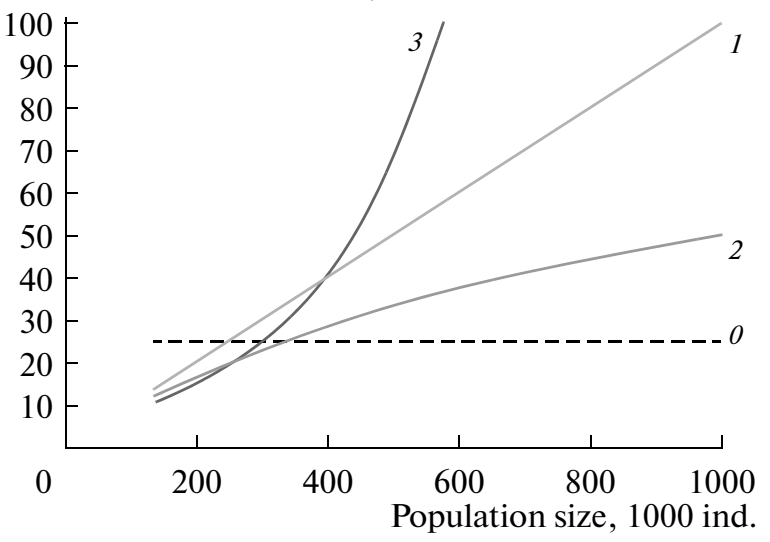

Fig. 5. Different types of response of hunting yield (number of killed deer) to change in wild reindeer population size in terms of the traditional ecological notion of functional response of predator to prey density (Solomon, 1949; Holling, 1963) used in model experiments.

Functional response: $(0)$ constant pressure independent of population size ("rigid hunting quota"); $(1)$ the first type of functional response: hunting pressure proportional to resource density; (2) the second type, characteristic of monophagous species: specific mortality from hunting decreases with an increase in reindeer population size; (3) the third type, characteristic of polyphagous species: mortality from hunting should first increase and then decrease with an increase in reindeer population size.

Population size, 1000 ind.

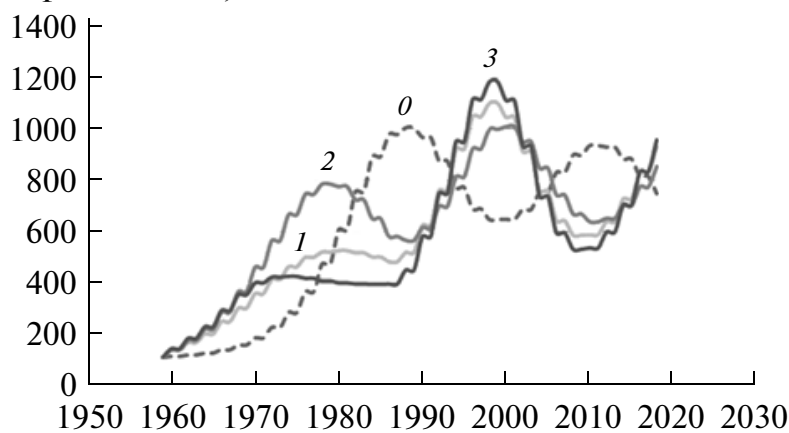

Fig. 6. Simulated population dynamics of wild reindeer on the Taimyr Peninsula under different types of hunting pressure (considered to cease in 1988). For designations $(0-3)$, see Fig. 5.

Simulations in which the type of hunting pressure (culling) was used as the external (control) variable showed that the lack of cyclic dynamics observed before the early 1990s was possible only in the case of linear dependence of mortality from hunting on reindeer population size (functional response of the first type). This dependence means that the practice of shooting reindeer at river crossings (and probably hunting on land as well) has no natural restrictions, and the intensity of killing (inclination of the linear 
graph) depends only on human choice. There is no feedback between reindeer abundance and proportion of reindeer killed, i.e., in fact hunting is not self-regulated. This type of culling distorts the natural cyclic (but on the whole stable) dynamics, and has to keep population size at a certain suboptimal level. Judging by the available data, the continuous nonselective culling of reindeer practiced until 1991 resulted in elimination of about $10 \%$ of the population. If this practice continued, it would have stabilized the longterm average size of the reindeer population on the Taimyr Peninsula at about 450000 ind. (almost half the potentially possible carrying capacity of the peninsula), with signs of cyclicity being retained to some extent.

\section{CONCLUSIONS}

Thus, the population group of wild reindeer on the Taimyr Peninsula is a metastable system with self-regulatory mechanisms. Nonselective elimination by hunting independent of population density should considerably distort the natural population dynamics, and the regular practice of such hunting should switch the dynamic regime of population demographics to a level lower than natural. This can have negative consequences, both ecological (disturbances of natural harmony in fragile northern ecosystems) and economic (loss of expected profit because of irrational exploitation of biological resources).

The amount of plant food resources depends on the abundance of primary consumers and, therefore, is also subject to change. The relationship between the intensity of migration flows and the state of vegetation requires further analysis. The cyclic dynamics of the reindeer population that theoretically should take the form of decaying oscillations is possible only if the level of the food supply is constant, a condition unlikely in reality.

\section{ACKNOWLEDGMENTS}

The authors are grateful to members of the Extreme North Agricultural Research Institute (Norilsk), especially N.F. Arsent'eva, for their substantial contribution to raw data processing.

This study was supported by the Russian Foundation for Basic Research, project no. 11-04-01153-a.

\section{REFERENCES}

Andreev, V.N., Assessment of reindeer abundance and migration routes by means of aerial surveys, Zool. Zh., 1961, vol. 40, no. 1, p. 16.

Batzli, G.O., Jung, H.G., and Guntenspergen, G., Nutritional ecology of microtine rodents: Linear forage-rate curves for brown lemmings, Oikos, 1981, no. 37, pp. 112-116.
Caughley, G., Analysis of Vertebrate Populations, London, 1977.

Geller, M.M., Migrations and seasonal distribution of wild reindeer from the Taimyr population, in Dikii severnyi olen' $v$ SSSR (Wild Reindeer in the Soviet Union), Moscow: Nauka, 1975, pp. 80-87.

Holling, C.S., The functional response of predators to prey density and its role in mimicry and population regulation, Mem. Enthomol. Soc. Canada, 1966, no. 45.

Kapitsa, S.P., Obshchaya teoriya rosta chelovechestva (The General Theory of the Growth of Humankind), Moscow: Nauka, 1999.

Klevezal, G.A., Printsipy $i$ metody opredeleniya vozrasta mlekopitayushchikh (Principles and Methods of Determining the Age of Mammals), Moscow: KMK, 2007.

Klevezal, G.A. and Kleinenberg, S.E., Opredelenie vozrasta mlekopitayushchikh po sloistym strukturam zubov $i$ kosti (Determining the Age of Mammals by Lamellar Structures of Teeth and Bones), Moscow: Nauka, 1967.

Kolpashchikov, L.A., Kuksov, V.A., and Pavlov, B.M., Ecological rationale for the upper limit to the size of the Taimyr population of wild reindeer, in Ekologiya i ratsional'noe ispol'zovanie nazemnykh pozvonochnykh Severa Srednei Sibiri (Ecology and Rational Management of Terrestrial Vertebrates in the North of Middle Siberia), Novosibirsk, 1983, pp. 3-14.

Kryazhimskiy, F.V., Maklakov, K.V., Morozova, L.M., and Ektova, S.M., Ecological modeling of Yamal tundra ecosystems: Traditional nature use as a factor of instability, Dokl. Biol. Sci., 2010, vol. 434, pp. 355-358.

Malygina, N.V., Le migrazione di renne nel Taimir centrale e orientale, Alto Serie IV, Anno CVX, 1997, vol. LXXIC, 111-117.

Malygina, N.V., Some features of migration movements of wild reindeer in eastern and central Taimyr (the Taimyr State Nature Reserve and bordering areas), Okhrana prirody Arktiki: Tez. dokl. mezhdun. simpoziuma pamyati V. Barentsa (Nature Conservation in the Arctic: Abstr. Int. Symp. in Memory of Willem Barents), Moscow, 1998, p. 157.

Malygina, N.V., Spatial distribution and migrations of wild reindeer in eastern Taimyr, Ekologicheskie problemy gornykh territorii: Mat-ly mezhdun. nauchn. konf., 18-20 iyunya 2002 (Ecological Problems in Mountain Areas: Proc. Int. Sci. Conf., June 18-20, 2002), Yekaterinburg: Akademkniga, 2002, pp. 189-193.

Malygina, N.V., Ob"ekt okhoty: dikii severnyi olen' (Rangifer tarandus L.) Vostochnogo Taimyra (Game to Hunt: Wild reindeer, Rangifer tarandus L. in Eastern Taimyr), Yekaterinburg: Bank Kul'turnoi Informatsii, 2005.

Malygina, N.V., Wild reindeer (Rangifer tarandus L.) in eastern Taimyr: Specific features of spatial distribution, $I z v$. Irkutsk. Gos. Univ., Ser. Biol. Ekol., 2010, no. 3, pp. 183190.

May, R.M., Biological populations obeying difference equations: Stable points, cycles, and chaos, J. Theor. Biol., 1975, vol. 51, no. 2, pp. 511-524.

May, R.M., Simple mathematical models with very complicated dynamics, Nature, 1976, vol. 261, pp. 459-467.

Messier, F., Huot, J., Le Henaff, D., and Luttich, S., Demography of the George River caribou herd: Evidence of 
population regulation by forage exploitation and range expansion, Arctic, 1988, vol. 41, no. 4, pp. 279-287.

Michurin, L.N., Wild reindeer in the Taimyr Peninsula and rational management of their stock, Extended Abstract of Cand. Sci. (Biol.) Dissertation, Moscow: VSKhIZO, 1965.

Odum, E., Basic Ecology, Philadelphia: Saunders, 1983.

Pianka, E.R., Evolutionary Ecology, New York: Harper and Row, 1978.

Rigler, F.H., The relation between concentration of food and feeding rate of Daphnia magna Straus, Can. J. Zool., 1961, no. 3, pp. 857-868.

Shvarts, S.S., Ekologicheskie zakonomernosti evolyutsii (Ecological Patterns of Evolution), Moscow: Nauka, 1980.
Stearns, S.C., The Evolution of Life Histories, Oxford: Oxford Univ. Press, 1992.

Svirezhev, Yu.M. and Logofet, D.O., Ustoichivost' biologicheskikh soobshchestv (Stability of Biological Communities), Moscow: Nauka, 1978.

Syroechkovskii, E.E., Severnyi olen' (The Reindeer), Moscow: Agropromizdat, 1986.

White, R.G., Bunnell, F.L., Gare, E., Skogland, T., and Hubert, B., Ungulates of arctic ranges, in Tundra Ecosystems: A Comparative Analysis, Bliss, L.C., Heal, O.W., and Moore, J.J., Eds., Cambridge: Cambridge Univ. Press, 1981, pp. 397-483.

Translated by P. Petrov 